\title{
Abundance of a chlorophyll $a$ precursor and the oxidation product hydroxychlorophyll $a$ during seasonal phytoplankton community progression in the Western English Channel
}

\author{
Deborah J. Steele ${ }^{\mathrm{a}, \mathrm{b}, \mathrm{c}, *}$, Glen A. Tarran ${ }^{\mathrm{a}}$, Claire E. Widdicombe ${ }^{\mathrm{a}}$, E. Malcolm S. Woodward ${ }^{\mathrm{a}}$, \\ Susan A. Kimmance ${ }^{a}$, Daniel J. Franklin ${ }^{b}$, Ruth L. Airs ${ }^{a}$ \\ ${ }^{a}$ Plymouth Marine Laboratory, Prospect Place, Plymouth, Devon PL1 3DH, United Kingdom \\ ${ }^{\mathrm{b}}$ Faculty of Science and Technology, Bournemouth University, Talbot Campus, Poole BH12 6BB, United Kingdom \\ ${ }^{\mathrm{c}}$ Current address: Departmento de Oceanografia, Instituto Milenio de Oceanografia, Universidad de Concepcion, Concepcion, Chile
}

\section{A R T I C L E I N F O}

Article history:

Available online $\mathrm{xxxx}$

\begin{abstract}
A B S T R A C T
This study presents the first in-situ measurements of the chlorophyll $a$ oxidation product, hydroxychlorophyll $a$ as well as the chlorophyll $a$ precursor, chlorophyll $a_{\mathrm{p} 276}$ conducted over an annual cycle. Chlorophyll $a$ oxidation products, such as hydroxychlorophyll $a$ may be associated with the decline of algal populations and can act as an initial step in the degradation of chlorophyll $a$ into products which can be found in the geochemical record, important for studying past climate change events. Here, hydroxychlorophyll $a$ and chlorophyll $a_{\mathrm{P} 276}$ were measured at the long-term monitoring station L4, Western Channel Observatory (UK, www.westernchannelobservatory.org) over an annual cycle (2012). Weekly measurements of phytoplankton species composition and abundance enabled detailed analysis of possible sources of hydroxychlorophyll $a$. Dinoflagellates, 2 diatom species, the prymnesiophyte Phaeocystis spp. and the coccolithophorid Emiliania huxleyi were all associated with hydroxychlorophyll $a$ occurrence. However, during alternate peaks in abundance of the diatoms, no association with hydroxychlorophyll $a$ occurred, indicating that the oxidation of chlorophyll $a$ was dependant not only on species but also on additional factors such as the mode of mortality, growth limiting factor (i.e. nutrient concentration) or phenotypic plasticity. Surface sediment samples contained 10 times more hydroxychlorophyll $a$ (relative to chlorophyll $a$ ) than pelagic particulate samples, indicating that more chlorophyll $a$ oxidation occurred during sedimentation or at the sediment-water interface, than in the pelagic environment. In addition, chlorophyll $a_{\mathrm{P} 276}$ correlated with chl- $a$ concentration, thus supporting its assignment as a chl- $a$ precursor.
\end{abstract}

(c) 2015 Elsevier Ltd. All rights reserved.

\section{Introduction}

The patterns of phytoplankton population growth and decline are governed by environmental (Berges and Falkowski, 1998; Berman-Frank et al., 2004; Alonso-Laita and Agustí, 2006; Smyth et al., 2014) and biotic (Brussaard et al., 1995) factors. During population decline, phytoplankton cells may alter their phenotype, enter into a new life history stage (Rousseau et al., 2007), or die

Abbreviations: PAR, photosynthetically active radiation; WCO, Western Channel Observatory; chl- $a$, chlorophyll $a$; HO-chl- $a, 13^{2}$-hydroxychlorophyll $a$; chl- $a_{\mathrm{P} 276}$, chlorophyll $a_{\mathrm{P} 276}$; HPLC, high performance liquid chromatography.

* Corresponding author. Tel.: +56 412203745.

E-mail addresses: deborahjanesteele@gmail.com (D.J. Steele), gat@pml.ac.uk (G.A. Tarran), clst@pml.ac.uk (C.E. Widdicombe), emsw@pml.ac.uk (E. Malcolm S. Woodward), sukim@pml.ac.uk (S.A. Kimmance), dfranklin@ bournemouth. ac.uk (D.J. Franklin), ruai@pml.ac.uk (R.L. Airs). due to grazing (Walsh, 1983), viral lysis (Suttle et al., 1990; Brussaard, 2004) or senescence (Walsh, 1983). The cells' functionality and primary productivity during population decline depends on the mode of mortality or growth limiting factor; For example nutrient concentration (Elser et al., 2007; Marañón et al., 2014), temperature (Regaudie-de-Gioux and Duarte, 2012), irradiance (Strzepek et al., 2012) and seasonal ice-cover (Arrigo et al., 2014; Wang et al., 2014).

Alterations to the chlorophyll structure can take place inside phytoplankton cells, particularly when the cell is disrupted during mortality, for example via grazing, viral lysis or environmental stress (Head and Horne, 1993; Head et al., 1994; Walker and Keely, 2004; Bale, 2010; Bale et al., 2011). Allomers, which are the early oxidation products of chlorophyll, can occur in phytoplankton cells, and are thought to be precursors of sedimentary porphyrins (Baker and Louda, 1986; Keely, 2006). It has been 
hypothesised that chlorophyll allomers arise due to a build-up of reactive oxygen species inside the cell, when oxidative stress overwhelms the cell defence mechanisms; i.e. during periods of physiological stress which may result in loss of membrane integrity and cell death (Franklin et al., 2012). However, it is known from long term (up to 10 year) dark incubations of phytoplankton cultures, that allomerization of chlorophyll $a$ can occur in anoxic conditions (Louda et al., 2011).

Chlorophyll degradation is often considered a generic stage in phytoplankton mortality, assessed by fluorescence in a bulk measurement e.g. by Turner fluorometry (Welschmeyer, 1994). However, some alteration products of chlorophyll $a$ (chl-a) have previously been associated with specific phytoplankton fates; for example chlorophyllide $a$ occurs in certain phytoplankton species (Jeffrey and Hallegraeff, 1987), and has been linked to senescence (Louda et al., 1998). Chlorophyll $a$ alterations involving demetallation, i.e. the loss of magnesium, forming products such as pheophytin $a$, have been linked with zooplankton grazing (Currie, 1962) and algal senescence (Louda et al., 1998, 2002). Chlorophyll alteration products are also found in recent sediments and are part of the pathway of chlorophyll conversion into porphyrins, which are found in the geochemical record (Treibs, 1936).

Some allomers are only subtly changed from the parent molecule, have unaltered fluorescence properties, and therefore require high resolution HPLC methods for detection, however, they have been well documented in marine and lake sediments (Walker et al., 2002; Hodgson et al., 2003, 2006; Squier et al., 2004). The allomers $13^{2}$-hydroxychlorophyll $a$ (HO-chl-a) and Mg-purpurin-7 dimethyl phytyl ester have also been detected in pelagic marine particulate samples (Walker and Keely, 2004; Bale et al., 2015). Some chlorophyll allomers are commonly detected but not assigned during routine analysis of marine phytoplankton extracts, and are quantified together with chlorophyll $a$ (Hooker et al., 2005). The production of allomers is therefore thought to be common in phytoplankton cells within a population, and may represent cells undergoing mortality. As HO-chl- $a$ is an early alteration product of chlorophyll $a$, its concentration will typically scale with chl- $a$ concentration in natural populations. It is hypothesised that during disruption to microalgal cells, as cell oxidative protection mechanisms breakdown, comparatively more HO-chl- $a$ will be produced, hence the ratio of HO-chl- $a$ to chl- $a$ will increase. Measurement of HO-chl- $a$ in the marine environment has been associated with the onset of phytoplankton bloom decline (Walker and Keely, 2004).

In UK shelf seas, changing environmental conditions throughout the year drive the progression of the phytoplankton assemblage through both promotion and limitation of growth. Monitoring the phytoplankton assemblage over a yearly cycle allows the measurement of allomers during the growth and decline phases of many different phytoplankton groups and individual species. When ambient conditions are conducive for growth, phytoplankton species will divide rapidly, creating blooms. These events are transient and phytoplankton populations will decline with altered conditions, like environmental limitation (Alonso-Laita and Agustí, 2006), viral infection (Jacobsen et al., 1996; Brussaard, 2004) or zooplankton grazing (Baudoux et al., 2008). The productive spring period in the Western English Channel (UK) is typically characterised by a rapid depletion of nitrate. The duration of the spring bloom is therefore controlled by nitrate availability (Smyth et al., 2010) and its species composition is typically dominated by chain forming diatoms (Southward et al., 2004; Widdicombe et al., 2010). Thermal stratification of the water column generally occurs in the summer period and a second bloom of smaller pennate or centric diatoms (e.g. Pseudo-nitzschia sp. or Leptocylindrus sp.) is usual (Widdicombe et al., 2010). A productive autumn period is typically induced in
September by mixing of the water column, replenishing nitrate to the surface waters (Smyth et al., 2010).

The measurement of chlorophyll $a$ allomers and other alteration products over an annual cycle may reveal patterns of occurrence linked to seasonal phytoplankton population turnover. Analysis of the population growth cycles is aided by the detection of chlorophyll $a_{\mathrm{P} 276}$ (chl- $\left.a_{\mathrm{P} 276}\right)$, which has one additional double bond in the phytyl chain (i.e. didehydrophytyl) compared to chlorophyll $a$ (Franklin et al., 2012) and is thought to be a precursor in chlorophyll $a$ biosynthesis (Rüdiger, 2006; Bale, 2010). Chl- $a_{\mathrm{P} 276}$ has been detected previously during analysis of phytoplankton cultures (Franklin et al., 2012). It therefore may be a useful proxy for phytoplankton population growth.

This work aimed to resolve the sources of HO-chl- $a$ in water column particulates and surface sediment and is the first presentation of hydroxychlorophyll $a$ and chlorophyll $a_{\mathrm{P} 276}$ over an annual cycle. Changes in particulate pelagic allomer abundance (relative to chlorophyll a) were related to temporal changes in phyto- and microzooplankton community structure, nutrient concentration, temperature, and light levels.

\section{Material and methods}

\subsection{Sampling protocol}

Samples for this study were collected between the 9th January and the 18th December 2012 and analysed as part of the long-term oceanographic and marine biodiversity time series study at the Western Channel Observatory (WCO, www.westernchannelobservatory.org.uk), from station L4, in the Western English Channel, $13 \mathrm{~km}$ southwest of Plymouth Breakwater, England, UK $\left(50^{\circ} 15.00^{\prime} \mathrm{N}, 4^{\circ} 13.02^{\prime} \mathrm{W}\right.$, Fig. 1$)$. Water samples were collected weekly (weather permitting) using $10 \mathrm{~L}$ Niskin bottles mounted on a rosette and temperature was measured by weekly Seabird 19+ CTD casts, deployed from the Plymouth Marine Laboratory vessel, RV Plymouth Quest. Surface photosynthetically active radiation (PAR) was calculated from a hyperspectral irradiance sensor (Satlantic, Halifax, Canada) monitoring continuously and mounted on to an autonomous buoy, controlled using a StorX logger (Satlantic). Rainfall measurements from Camborne MET station $\left(50^{\circ} 21.30^{\prime} \mathrm{N}, 5^{\circ} 3.00^{\prime} \mathrm{W}\right), \sim 80 \mathrm{~km}$ from station L4 (Fig. 1), were accessed from www.metoffice.gov.uk.

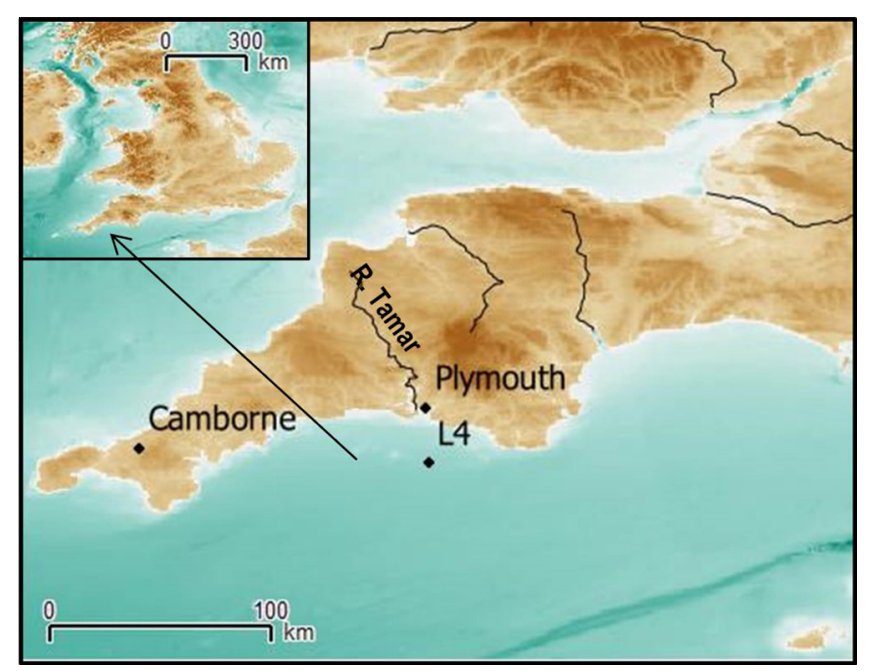

Fig. 1. Location of station L4 within the western English Channel, UK. Bathymetry map was derived from www.gebco.net. 


\subsection{Nutrients}

Measurement of the major nutrients including nitrate, phosphate and silicate were taken weekly from fresh samples throughout the depth profile $(2,10,25$ and $50 \mathrm{~m})$; water samples were stored in cool boxes prior to analysis and filtered through an Acrodisc Supor PF membrane filter (with pore size $0.8 / 0.2 \mu \mathrm{m}$ ). Nutrient concentrations were determined using the procedures described in Woodward and Rees (2001) as follows; phosphate (Zhang and Chi, 2002), silicate (Kirkwood, 1989), nitrate and nitrite ions (Brewer and Riley, 1965) and nitrite analysis (Grasshoff, 1976).

\subsection{Phytoplankton enumeration and identification}

Two methods were used to enumerate phytoplankton in different pico-, nano- and microplankton size fractions. Firstly, fresh samples from 2, 10, 25 and $50 \mathrm{~m}$ depth (stored in a cool box until analysis in the laboratory) were analysed on an Accuri C6 flow cytometer with Milli-Q sheath fluid, triggered on forward scatter and red fluorescence to enumerate cells (Tarran and Bruun, 2015). A $500 \mu \mathrm{L}$ sample volume was processed at approx. $100 \mu \mathrm{L} \mathrm{min}{ }^{-1}$. Cells were separated into 7 groups according to red and orange fluorescence and side scatter; Synechococcus, picoeukaryotes, coccolithophorids, cryptophytes, Phaeocystis single cells, small dinoflagellates $(<20 \mu \mathrm{m})$ and other nanoeukaryotes. The flow cytometry data for the Phaeocystis single cells and small dinoflagellates are speculative, and relied on verification of the significant presence of Phaeocystis or small dinoflagellates by microscopy at the same time as the appearance of clusters of events in flow cytometric density plots of forward light scatter versus red fluorescence, used to discriminate other nanophytoplankton groups.

The second method considered only plankton sampled from $10 \mathrm{~m}$ depth which were fixed upon collection with $2 \%$ (final concentration) Lugol's iodine (Widdicombe et al., 2010). Phytoplankton were identified by microscopy to species level where possible, following the protocol of Widdicombe et al. (2010) and enumerated using the Utermöhl (1958) technique. Autotrophs were divided into 5 functional groups; diatoms, coccolithophorids, dinoflagellates, Phaeocystis spp. and phytoflagellates, which includes 2-6 $\mu \mathrm{m}$ flagellated chlorophytes and prasinophytes (Holligan and Harbour, 1977). The microzooplankton groups: heterotrophic dinoflagellates, ciliates and zooflagellates were also identified and enumerated. Biomass was calculated from measurements of the average dimensions of each species which were then converted to cellular volumes (Kovala and Larrance, 1966) and carbon content (Menden-Deuer and Lessard, 2000).

\subsection{Photosynthetic pigments and alteration products}

For pigments, $1 \mathrm{~L}$ water samples from 2, 10, 25 and $50 \mathrm{~m}$ depth were filtered through $25 \mathrm{~mm}$ GF/F filters on board the Plymouth Quest, immediately after sampling. The filters were snap frozen in liquid nitrogen and stored in liquid nitrogen at Plymouth Marine Laboratory until analysis. Samples were extracted under dim light conditions on ice, in $2 \mathrm{~mL} 90 \%$ acetone by sonication (Sonics Vibracell probe, $35 \mathrm{~s} 40 \mathrm{~W}$ ), followed by a soaking period (total extraction time $=1 \mathrm{~h}$ ). Extracts were clarified by centrifugation (Centaur 2, $4000 \mathrm{rpm}, 5 \mathrm{~min}$ ), and by filtration $(0.2 \mu \mathrm{m}$, $17 \mathrm{~mm}$ Teflon syringe filters, DHI, Denmark). Extracts were analysed on an Accela HPLC instrument (ThermoScientific, UK), comprising an Accela quarternary pump, thermostated autosampler, thermostated column compartment and photodiode array detector using a method based on Zapata et al. (2000). A $200 \mu \mathrm{L}$ aliquot of extract was mixed with $80 \mu \mathrm{L}$ water in the autosampler, and
$25 \mu \mathrm{L}$ of this mix was injected onto the column. A Waters C8 Symmetry column $(150 \times 2.1 \mathrm{~mm} ; 3.5 \mu \mathrm{m}$ particle size $)$ was used at a flow rate of $200 \mu \mathrm{L} \mathrm{min}^{-1}$. Mobile phase composition was as described in Zapata et al. (2000). Samples were analysed within $24 \mathrm{~h}$ of extraction during which time they were maintained at $4{ }^{\circ} \mathrm{C}$ in the dark in the autosampler. The following quality assurance protocols are adhered to for pigment analysis: A mixed pigment standard (DHI, Denmark) is analysed daily before sample extraction to check resolution of pigment critical pairs (MgDVP/chl- $c_{2}$, violaxanthin/19-hexfucoxanthin, zeaxanthin/lutein, and Divinyl chl-a/chl-a) and consistency of retention times (Van Heukelem and Hooker, 2011); During analyses, triplicate injections of chl- $a$ standard were performed to check response factor. Accuracy of the repipette was checked daily by weighing aliquots of extraction solution expelled by the repipette. Multipoint calibration of 19 pigments is performed annually by injection of pigments standards obtained from DHI. For calibration curves, the standards were used to prepare a dilution series, comprising three solutions bracketing the limit of quantification, and three bracketing the expected sample concentration.

Sediment samples: A multicorer was used to collect eight replicate cores at station L4. Surface sediment samples $(1 \mathrm{~mL})$ were taken using the barrel of a $2.5 \mathrm{~mL}$ syringe and immediately frozen at $-20^{\circ} \mathrm{C}$ in the dark. Samples of surface sediment $(2-3 \mathrm{~g})$ were thawed and centrifuged to remove excess water. Sediment was transferred to a pre-weighed extraction tube to which $3 \mathrm{~mL} \mathrm{90 \%}$ acetone was added. Extracts were kept on ice in the dark during extraction. Samples were sonicated (Sonics Vibracell probe, $35 \mathrm{~s}$ $40 \mathrm{~W}$ ), before centrifugation (Eppendorf, $4000 \mathrm{rpm}, 5 \mathrm{~min}, 4^{\circ} \mathrm{C}$ ), and the supernatant decanted. The procedure was repeated until no additional pigment was extracted. For quantification of hydroxychlorophyll $a$, samples were injected on the Accela system for phytoplankton pigments (described above).

Selected samples were analysed by LC/MS ${ }^{\mathrm{n}}$ (replicate samples freshly extracted for LC/MS analysis) for assignment of components. LC/MS ${ }^{\mathrm{n}}$ was performed using an Agilent 1200 HPLC comprising a G1313A binary pump, a G1377B thermostated autosampler, a G1317A thermostated column compartment and a G1316B photodiode array detector coupled to an Agilent 6330 ion trap mass spectrometer via an atmospheric pressure chemical ionisation (APCI) source. HPLC conditions were as for Zapata et al. (2000). Post-column addition of formic acid $\left(300 \mu \mathrm{L} \mathrm{h}^{-1}\right)$ was used to aid ionisation of metallated components (Airs and Keely, 2000). MS settings were as follows: Ionisation mode: positive, drying temperature $350{ }^{\circ} \mathrm{C}$, vaporiser temperature $450{ }^{\circ} \mathrm{C}$, nebulliser pressure 60 PSI, drying gas flow rate $5 \mathrm{~L} \mathrm{~min}^{-1}$, capillary voltage $-4500 \mathrm{~V}$. The scan range was $m / z 400-1100$. MS ${ }^{\mathrm{n}}$ utilised an ion trap to select ions of interest for dissociation to aid component assignment. $\mathrm{MS}^{\mathrm{n}}$ settings were used as follows: Synchronous Precursor Selection (SPS) on, number of precursor ions 2 , and isolation width $3 \mathrm{~m} / z$. Components were assigned based on relative retention time, on-line UV/vis spectra, protonated molecule and dissociation data (Airs et al., 2001).

\section{Results and discussion}

\subsection{Physical conditions}

Conditions at L4 in early 2012 were typical for the winter season, with temperature consistent throughout the water column at $\sim 10^{\circ} \mathrm{C}$ from January to May (Fig. 2A) (Smyth et al., 2010). By mid-May the surface and bottom temperatures differed by $>+0.1{ }^{\circ} \mathrm{C}$ (Fig. 2A), indicating the existence of an early summer thermocline (Smyth et al., 2010). Although this is consistent with the expected timing for the onset of stratification, the water 


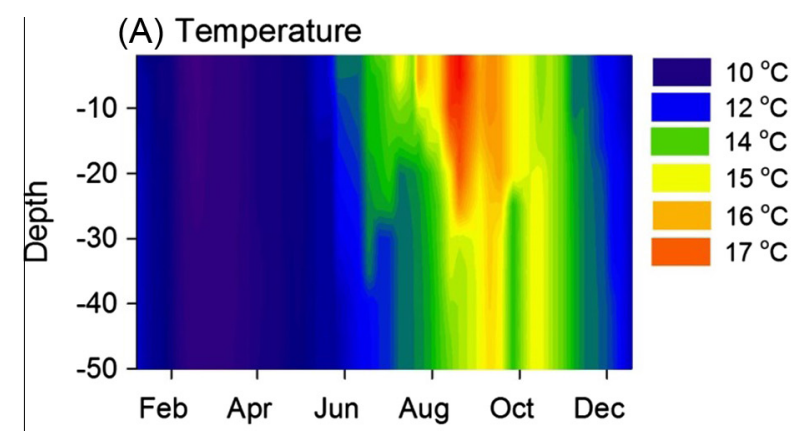

(B) Rainfall

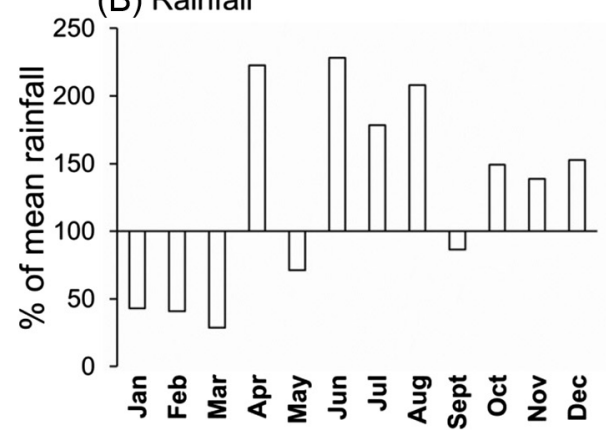

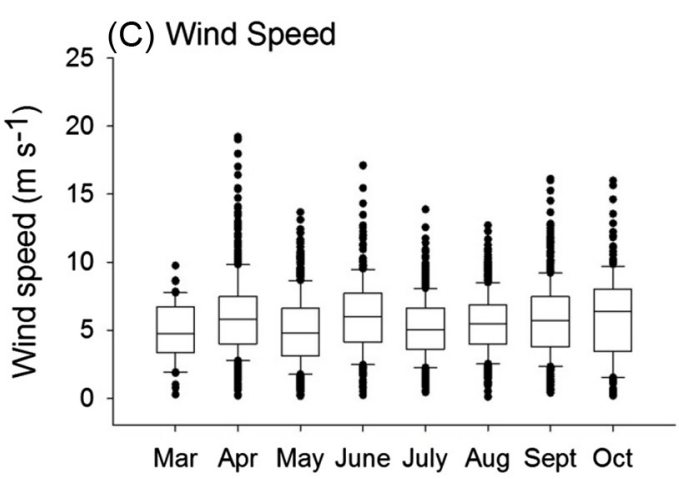

(D) PAR

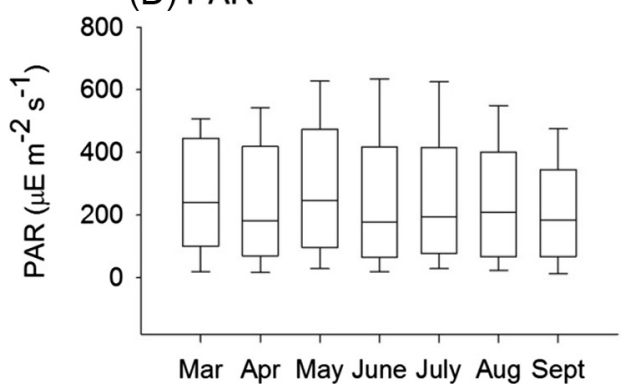

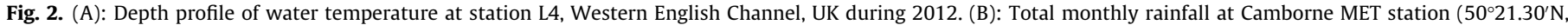

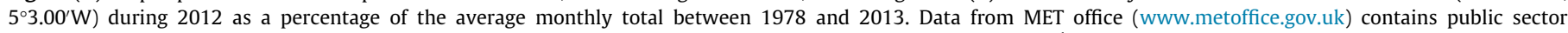

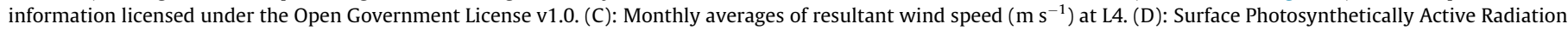
(PAR) at L4. Box represents the interquartile range. Bars represent the 10th and 90th quartiles. Points represent all outliers.

column was re-mixed by storm events in the spring and summer months (Fig. 2B); in April, June and August rainfall was $>200 \%$ greater than historical averages (Fig. 2B). Wind speeds of over $15 \mathrm{~m} \mathrm{~s}^{-1}$ were recorded in April, June, September and October (Fig. 2C). These periods of high wind speed indicated storm events that re-mixed the water column. During the months of increasing water temperature (from April) the monthly average photosynthetically active radiation (PAR) levels were not greater than the average winter levels (Fig. 2D). Around a 10-fold increase is expected in daily PAR levels from January to July (Smyth et al., 2010), hence the physical conditions during the spring months of March to May were not typical of the L4 spring bloom period compared to historical data.

\subsection{Nutrient concentrations at L4 during 2012}

Nitrate concentrations during 2012 showed a typical annual pattern for the L4 station, with a maximum of $7.9 \mu \mathrm{M}$ in January (Fig. 3A). Nitrate then declined rapidly to below the detection limit $(0.02 \mu \mathrm{M})$ during the spring bloom period in April as is typical for the L4 station (Southward et al., 2004; Smyth et al., 2010). During periods of May and July surface nitrate concentration ranged between $0.2 \mu \mathrm{M}$ and $2.6 \mu \mathrm{M}$. Summer peaks in surface nitrate concentration, up to $2.26 \mu \mathrm{M}$, have been associated previously with elevated inputs from the nearby River Tamar (Fig. 1) after high rainfall ( $164 \%$ of the summer time historical average) (Rees et al., 2009).

Phosphate and silicate lagged the nitrate trend by 1-2 months, with maximum concentrations in February of $0.62 \mu \mathrm{M}$ and $4.06 \mu \mathrm{M}$ respectively (Fig. $3 \mathrm{~B}$ and $\mathrm{C}$ ), which are as expected for L4 (Southward et al., 2004; Smyth et al., 2010). During the spring and summer months, concentrations of silicate and phosphate were reduced in the surface waters, however, concentrations at 25 and $50 \mathrm{~m}$ depth increased either due to remineralisation from grazers (Fileman et al., 2010) or the establishment of the seasonal thermocline (Smyth et al., 2010). As expected, the winter silicate maximum at L4 of $5.54 \mu \mathrm{M}$ occurred in December (Fig. 3C) and has been attributed to an alternate source of silicate other than Atlantic water, which is most likely to be outflow from the River Tamar (Fig. 1) (Smyth et al., 2010).

\subsection{Phytoplankton community structure and progression}

The L4 phytoplankton community abundance peaked twice in 2012; during the spring with maximum abundance on 27th February (measured by flow cytometry) and unusually for station L4, during the autumn months, with maximum abundance of 30,400 cells $\mathrm{mL}^{-1}$ recorded on 10 th September (measured by flow cytometry, Fig. 4A). Synechococcus and picoeukaryotes numerically dominated the phytoplankton community throughout the year, with picoeukaryotes dominating during periods of highest phytoplankton abundance and Synechococcus in early February and in August and November. (Fig. 4A). During the spring bloom period of April to July, increases in Synechococcus, Phaeocystis spp. and diatoms, in particular Chaetoceros socialis and Guinardia delicatula, were all significant contributors to the increase in total phytoplankton abundance. The spring bloom period at L4 is well known to be dominated by chain-forming diatoms, however, unusually for L4, another significant diatom bloom occurred in October.

Although picoeukaryotes and Synechococcus numerically dominated the water column throughout most of the year, the nanoand microeukaryote size fractions (i.e. those enumerated by microscopy) contributed most to phytoplankton biomass throughout the year (Kovala and Larrance, 1966; Menden-Deuer and Lessard, 2000). The eukaryote population density maxima measured by microscopy were 4700 cells $\mathrm{mL}^{-1}$ and 5800 cells $\mathrm{mL}^{-1}$ on the 14th of May and the 8th of October respectively (Fig. 4B). Phytoplankton biomass followed a similar trend to population 
(A) Nitrate
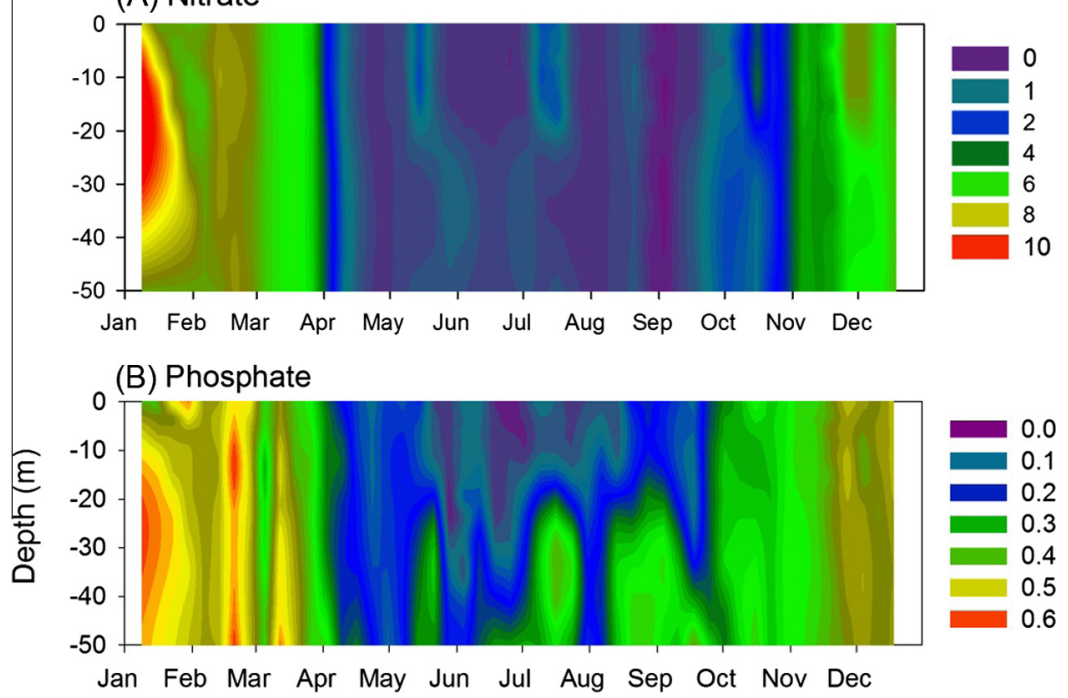

(C) Silicate

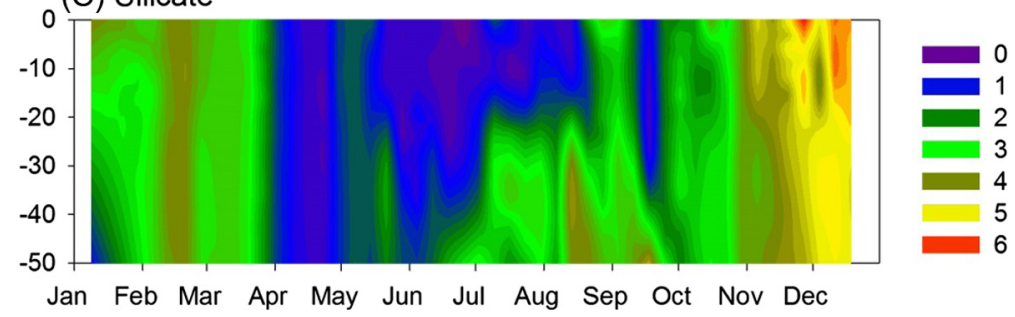

Fig. 3. Depth profiles of nutrient concentrations $(\mu \mathrm{M})$ at sample station L4, Western English Channel, UK, during 2012; (A): Nitrate, (B): Phosphate and (C): Silicate.

density and ranged from 6 to $651 \mathrm{pg} \mathrm{C} \mathrm{mL}^{-1}$. An exception occurred during the autumn bloom period in October, as phytoplankton biomass only reached $65 \mathrm{pg} \mathrm{C} \mathrm{mL}^{-1}$ (Fig. 4B). Microzooplankton had several peaks in abundance during the spring months with a maximum of $900 \mathrm{~mL}^{-1}$ in mid-June. During the rest of the year microzooplankton abundance was low, ranging from 2 to $80 \mathrm{~mL}^{-1}$ (Fig. 4C). Microzooplankton biomass followed a separate trend and generally increased from the winter to autumn months, from $1 \mathrm{pg} \mathrm{C} \mathrm{mL}^{-1}$ to a maximum of $36 \mathrm{pg} \mathrm{C} \mathrm{mL}^{-1}$ on the 17th September (Fig. 4C).

\subsection{Seasonality of chlorophyll a, allomer and precursor}

At the beginning of 2012 the winter concentrations of chlorophyll $a$ at station L4 were between 0.13 and $0.5 \mu \mathrm{g} \mathrm{L}^{-1}$ (Fig. 5A), chl- $a$ in surface waters then increased to a maximum concentration of $4.48 \mu \mathrm{g} \mathrm{L}^{-1}$ on 11th April. These surface concentrations were within the range expected for L4 (Southward et al., 2004; Smyth et al., 2010). The first chl-a maximum on 11th April $\left(11 \mu \mathrm{g} \mathrm{L}^{-1}\right)$ corresponded to a minor peak in phytoplankton abundance (Fig. 4A and B) possibly due to a Phaeocystis spp. bloom which had a concurrent maximum abundance (Fig. 7A). This chl- $a$ maximum in April was coincident with a peak in chl- $a$ concentration in the surface sediment (Tait et al., 2015). A second chl- $a$ maximum occurred at $50 \mathrm{~m}$ depth on the 28th of May $\left(10.9 \mu \mathrm{g} \mathrm{L}^{-1}\right)$, just after the spring maximum eukaryote phytoplankton abundance as measured by microscopy (Fig. 4B) and may have resulted from sinking diatom cells, as their peak abundance preceded the deep chlorophyll maximum. During September and October chl- $a$ concentration increased throughout the water column to an autumn maximum of $2.4 \mu \mathrm{g} \mathrm{L}^{-1}$.

The allomer hydroxychlorophyll $a$ was detected throughout the year at station L4, and exhibited seasonal variations (Fig. 5B).
Previous time-series of HO-chl- $a$ in pelagic waters have been limited to the bloom period (Walker and Keely, 2004; Bale et al., 2010), hence, these are the first reported measurements over an almost complete annual cycle. Hydroxychlorophyll $a$ concentration had a similar annual distribution to chlorophyll $a$. A spring peak occurred on the 11th April throughout the water column with a maximum concentration of $548 \mathrm{ng} \mathrm{L}^{-1}$ at $10 \mathrm{~m}$ depth (Fig. 5B). Smaller peaks in pelagic particulate hydroxychlorophyll $a$ occurred on the 28th May at $50 \mathrm{~m}$ and on the 11th June at $2 \mathrm{~m}$. In comparison, concentrations of up to $\sim 600 \mathrm{ng} \mathrm{L}^{-1}$ of hydroxychlorophyll $a$ were also measured during a spring bloom of Chaetoceros in the Celtic Sea (Walker and Keely, 2004).

To the best of our knowledge, this is the first report of hydroxychlorophyll $a$ in benthic marine sediments. HO-chl- $a$ was detected in all analysed sediment samples with a range of concentration from 6.7 to $170 \mathrm{ng} \mathrm{g}^{-1}$ dry sediment (Fig. 5C). This is comparable with the HO-chl-a concentration detected in sinking particles (Bale et al., 2015) and freshwater lake surface sediments (Walker et al., 2002).

This study is the first report of chl- $a_{\mathrm{P} 276}$ from natural phytoplankton assemblages. The annual cycle of chlorophyll $a$ concentration was also paralleled by chlorophyll $a_{\mathrm{P} 276}$ concentration (Fig. 5D). A spring peak of $143 \mathrm{ng} \mathrm{L}^{-1}$ chl- $a_{\mathrm{P} 276}$ at $10 \mathrm{~m}$ depth on 11th April co-occurred with peaks in chl-a concentration (Fig. 5A) and phytoplankton biomass (Fig. 4B). The maximum concentration of chl- $a_{\mathrm{P} 276}\left(210 \mathrm{ng} \mathrm{L}^{-1}\right)$ occurred on the 28 th May at $50 \mathrm{~m}$ depth and paralleled the maximum chl- $a$ concentration at $50 \mathrm{~m}$.

\subsection{Allomer hydroxychlorophyll a}

\subsubsection{Seasonality relative to phytoplankton blooms}

The annual cycle of hydroxychlorophyll $a$, relative to chl-a, i.e. the HO-chl- $a$ to chl- $a$ ratio, was discrete from that of chl- $a$ 

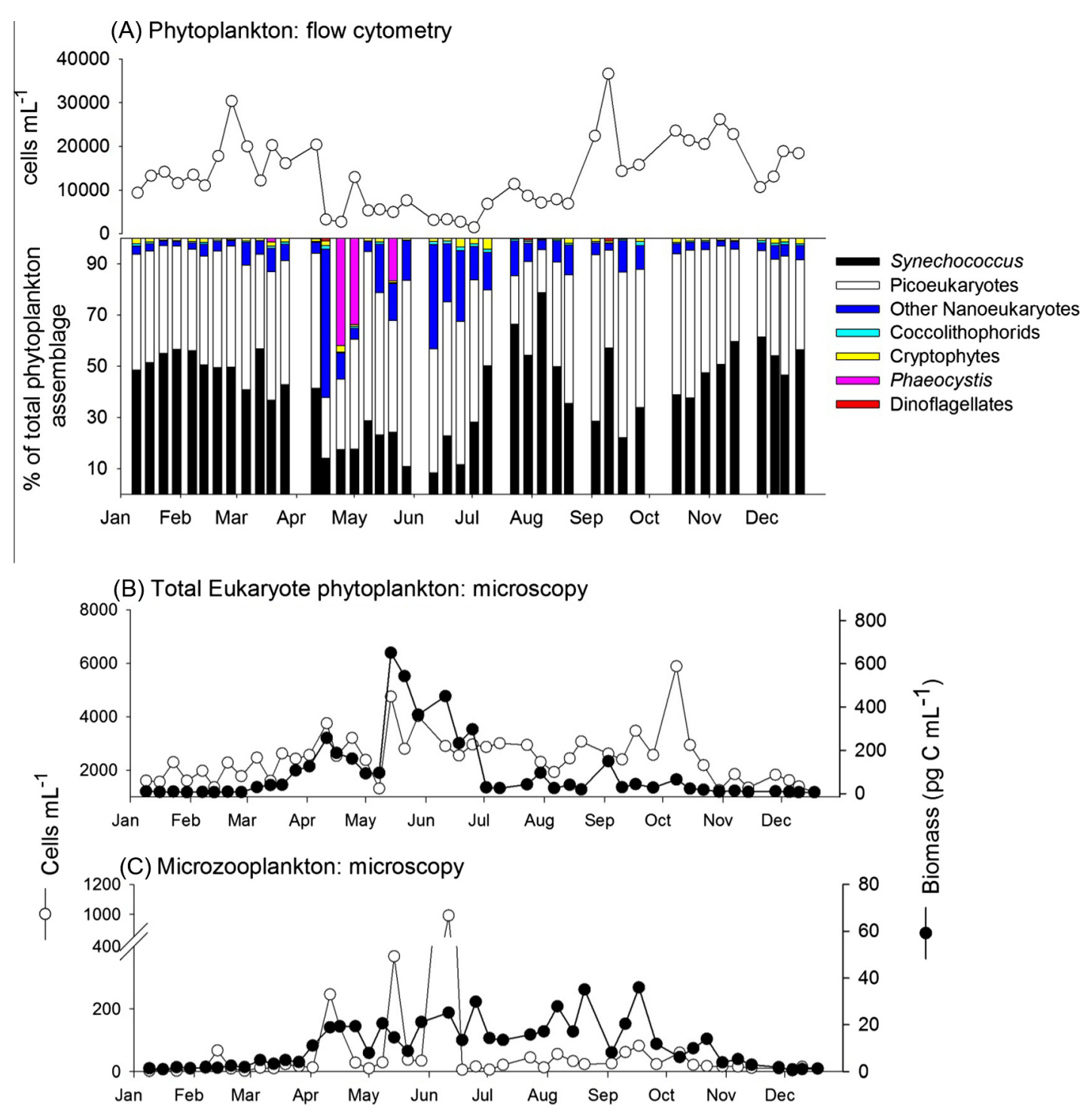

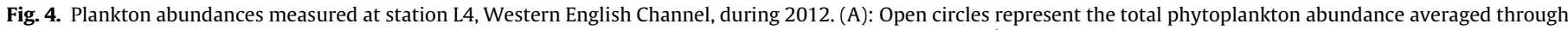

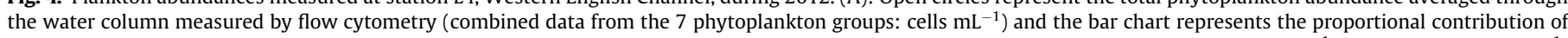

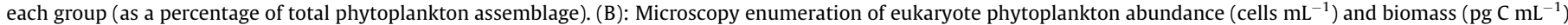
from $10 \mathrm{~m}$ depth, and (C): microzooplankton abundance and biomass from $10 \mathrm{~m}$ depth.

(Figs. 5A and 6). At the beginning of the year during February and March, the ratio of HO-chl- $a$ to chl- $a$ was between 0.008 and 0.029 (Fig. 6A). A maximum ratio of 0.093 was detected in surface waters $(2 \mathrm{~m})$ in April. These measurements were within the ranges of the HO-chl- $a$ to chl- $a$ ratios previously reported: during a North Atlantic spring bloom, where the pelagic maximum ratio of HO-chl- $a$ to chl- $a$ was $\sim 0.05$ (Bale, 2010) and during a spring bloom of Chaetoceros in the Celtic Sea where the HO-chl- $a$ to chl- $a$ ratios can be calculated to be between $\sim 0.05$ and $\sim 0.5$ from the work of Walker and Keely (2004). Unidentified chlorophyll $a$ allomers have been reported from measurements in the Baltic Sea as $14 \%$ of the total chloropigments (i.e. a ratio of allomers to total chloropigments of 0.14) (Szymczak-Żyła and Kowalewska, 2007).

In periods where the water column contained a thermocline, from mid-May onward (Fig. 2A), HO-chl-a was found in higher concentrations (relative to chl-a) below the thermocline, at $25 \mathrm{~m}$ and $50 \mathrm{~m}$ depth. Stratification of phosphate concentration occurred during this period (Fig. 3C) when higher concentrations occurred below $25 \mathrm{~m}$. From mid-May to late September phosphate may have been a limiting factor for phytoplankton growth at station L4 in the upper $25 \mathrm{~m}$ of the water column. The elevated HO-chl- $a$ to chl- $a$ ratio below $25 \mathrm{~m}$ may be attributed to sinking phytoplankton cells, presumably some of which were therefore phosphate-limited. The HO-chl- $a$ to chl- $a$ ratio then decreased during May and June to between 0.014 and 0.045 , before increasing during the summer months, with a maximum ratio of 0.059 ; ratio values remained in this range until late October (Fig. 6A). The HO-chl- $a$ to chl- $a$ ratio then decreased to between 0.006 and 0.053 for the remainder of the year.

Hydroxychlorophyll $a$ was detected in the surface sediment at station $\mathrm{L} 4$ with a HO-chl- $a$ to chl- $a$ ratio ranging from 0.07 to 0.49 (Fig. 6B); up to 10 times higher than the overlying pelagic levels. A similar HO-chl- $a$ to chl- $a$ ratio was measured in freshwater lake surface sediments of $\sim 0.25$ (Walker et al., 2002). Unassigned chlorophyll allomers have previously been quantified in marine sediments from the Baltic Sea, where they accounted for $10 \%$ of the chloropigments (Szymczak-Żyła and Kowalewska, 2007); they have also been detected in marine sediments from the Louisiana shelf (Chen et al., 2003), the Levantine Basin and 
(A) Pelagic particulate chlorophyll a

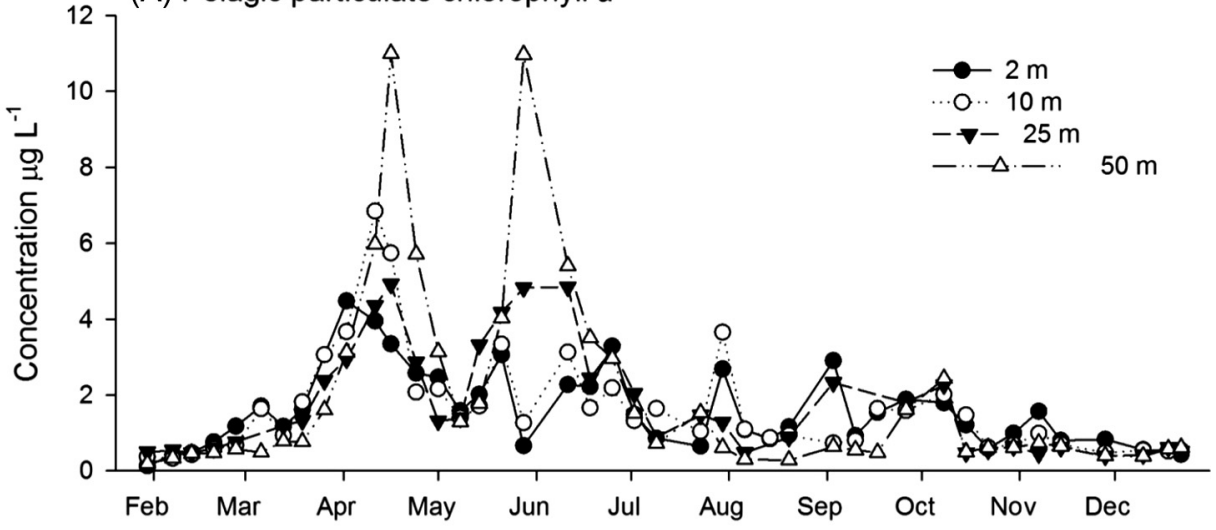

(B) Pelagic particulate hydroxychlorophyll a
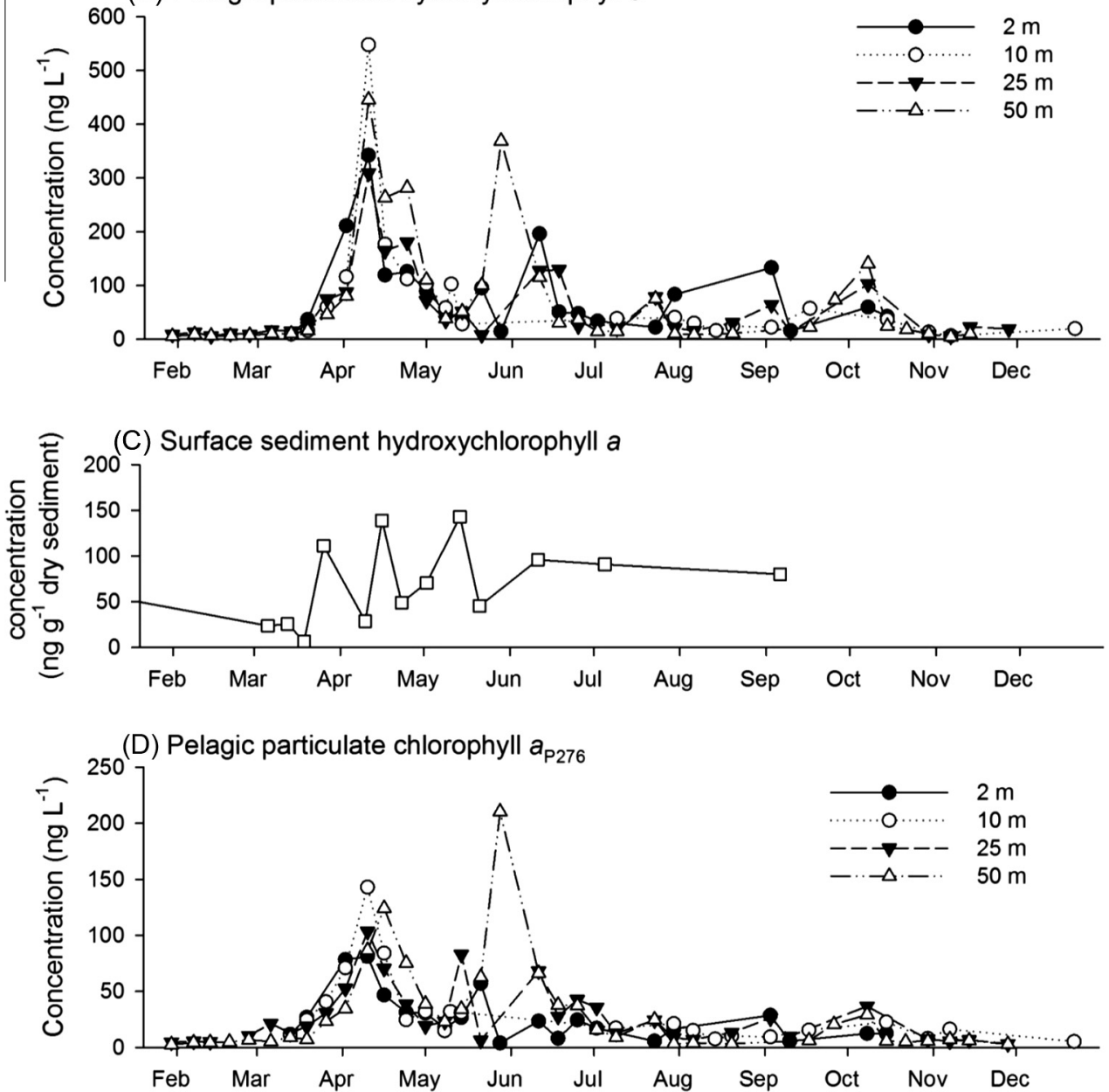

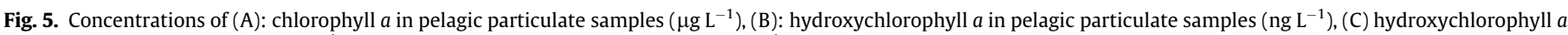

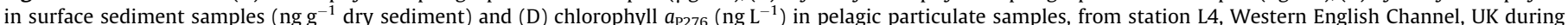
2012.

the Mediterranean Ridge (Cariou-Le Gall et al., 1998), but were not quantified.

A peak in the surface sediment HO-chl- $a$ to chl- $a$ ratio on the 21st May of 0.322 was coincident with the water column phytoplankton maximum biomass (Fig. 4B). The high concentrations of hydroxychlorophyll $a$ (relative to chl- $a$ ) in the surface sediment indicate that the majority of chl- $a$ oxidation occurred during the sedimentation process. This is consistent with a previous report of increased hydroxychlorophyll $a$ to chl- $a$ ratios measured in sinking particulates, collected by sediment traps (0.085), compared to suspended particulates sampled by Niskin bottles (0.03) (Bale et al., 2015).

\subsubsection{Contributors to pelagic hydroxychlorophyll a maxima}

During April, hydroxychlorophyll $a$ was elevated throughout the water column. A surface maximum in the ratio of HO-chl- $a$ to chl- $a$ of 0.093 was recorded on the 11th April (Fig. 6B), which coincided with maximum recorded Phaeocystis abundance 
(A) HO-chl-a:chl-a Water column average

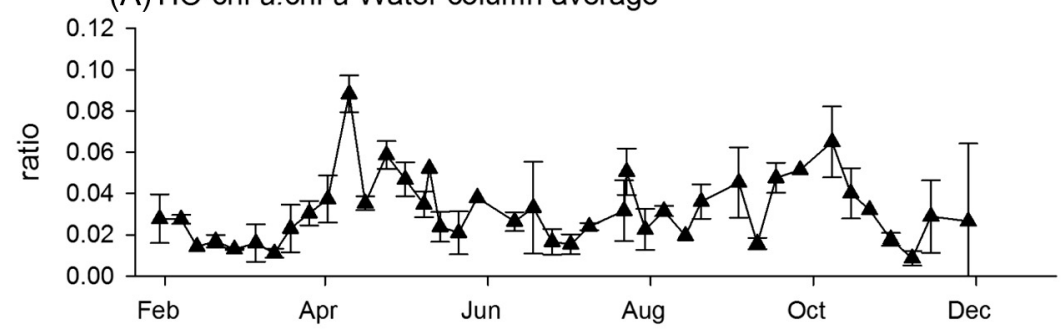

(B) HO-chl-a:chl-a Depth profile

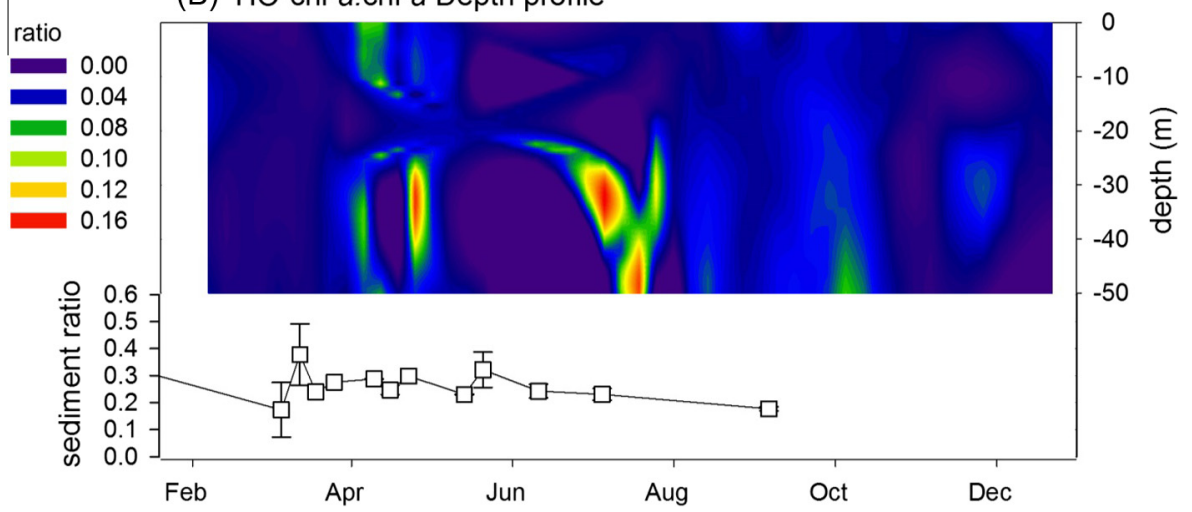

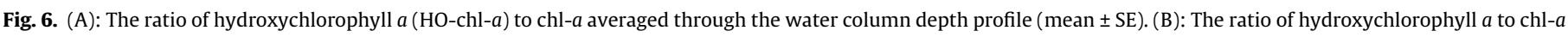
in the depth profile (contour plot) and surface sediment ( $\square$ ) from station L4, Western English Channel, UK during 2012.

measured by microscopy at $10 \mathrm{~m}$ (Fig. 7A). The maximum Phaeocystis and hydroxychlorophyll $a$ abundances occurred between the 2 nd and 16 th April. The temporal sampling resolution $\left(<1\right.$ week $^{-1}$ ) does not allow a more precise prediction of the timing of the phytoplankton or allomer maximum abundances. A second maximum ratio of HO-chl- $a$ to chl- $a$ on 24th April at 25 and $50 \mathrm{~m}$ may be due to the senescing and sinking Phaeocystis cells which were detected at $50 \mathrm{~m}$ as single cells by flow cytometry (Fig. 7A). During the spring months of March to May the HO-chl- $a$ to chl- $a$ ratio was significantly correlated with the summated measurements of Phaeocystis abundance by microscopy and flow cytometry $(P=0.032$, Spearman Rank correlation coefficient $=0.304$ ).

At station L4 during the Phaeocystis spp. bloom the N/P ratio declined from 15 to $<1$, indicating that nitrate availability possibly limited Phaeocystis spp. population growth. This has been previously reported in a Phaeocystis sp. bloom in the North Sea near the Belgian coast (Lancelot, 1983). A minor peak in microzooplankton abundance also occurred on 11th April (Fig. 4C), indicating grazing as an additional contributor of Phaeocystis spp. decline as observed previously in Phaeocystis spp. blooms in the Dutch Wadden Sea and the coastal North Sea (Admiraal and Venekamp, 1986). In addition, viral infection is a possible cause of Phaeocystis spp. bloom decline, however it was not measured in this study.

The elevated ratio of HO-chl- $a$ to chl- $a$ in the water column on the 24th April had a maximum of 0.068 at $25 \mathrm{~m}$ depth. This was co-incident with the maximum abundance at $10 \mathrm{~m}$ of the diatom Guinardia delicatula (Fig. 7B). This bloom began on the 26th March which was co-incident with the start of a decline in the nitrate to phosphate ratio (Fig. 8); during which the surface N/P ratio reduced from 14.4 to 0.5 on the 24th April. By the 8th May G. delicatula had become infected with a parasite, Pirsonia sp. and the bloom was waning (Widdicombe, pers comm.). After this time G. delicatula abundance declined and the N/P ratio began to rise; it can therefore be deduced that population growth of G. delicatula was possibly limited by both nitrate availability and parasitic infection, as previously reported in a North Sea Phaeocystis population (Admiraal and Venekamp, 1986; Veldhuis et al., 1986).

G. delicatula also had an autumn bloom which peaked on the 3rd September; however, no hydroxychlorophyll a maximum was detected at this time (Figs. 7B and 6B). During this bloom surface nitrate concentration dropped from $0.85 \mu \mathrm{M}$ to below the limit of detection (Fig. 3A) and surface phosphate concentration decreased from $0.17 \mu \mathrm{M}$ to $0.11 \mu \mathrm{M}$ (Fig. 3C). The $\mathrm{N} / \mathrm{P}$ ratio decreased from 5 to 0 (Fig. 8), hence implying that nitrate was limiting population growth of G. delicatula during its autumn bloom. This indicates that the April maximum of hydroxychlorophyll $a$ may have been associated with the parasitic infection of $G$. delicatula by Pirsonia sp.

An autumn maximum of hydroxychlorophyll $a$ occurred at $50 \mathrm{~m}$ on 8th of October, with a HO-chl- $a$ to chl- $a$ ratio of 0.084 . This was concurrent with a Chaetoceros socialis bloom (Fig. 7C), during which concentrations of both nitrate and phosphate increased, hence this bloom was assumed not to be nitrate or phosphate limited. C. socialis also bloomed in the spring with a maximum abundance on the 14th of May, however during this bloom the HO-chl-a to chl- $a$ ratio was not elevated. A sporadic period of nutrient input occurred during this time (Fig. $3 \mathrm{~A}$ ) and nitrate concentration reached $2.62 \mu \mathrm{M}$. By the end of the bloom on the 21st of May, nitrate concentration had declined to $0.08 \mu \mathrm{M}$, hence this bloom may have declined due to nitrate limitation.

\subsubsection{Contributors to minor peaks in pelagic hydroxychlorophyll a}

Several minor peaks in hydroxychlorophyll $a$ occurred during the summer and autumn months. On the 23rd July the HO-chl- $a$ to chl- $a$ ratio increased at 25 and $50 \mathrm{~m}$ to a maximum of 0.057 ; at this time the water column was stratified with a mixed layer depth (MLD) of $15 \mathrm{~m}$. However, on the 26th September the ratio at $50 \mathrm{~m}$ was 0.052 (Fig. 6B) and the water column was completely mixed. These minor peaks were paralleled by increases in coccolithophorid abundance (Fig. 9A) which accounted for $<1 \%$ of the phytoplankton detected. The coccolithophore E. huxleyi has been studied in culture and shown not to alter its HO-chl- $a$ to chl- $a$ ratio 

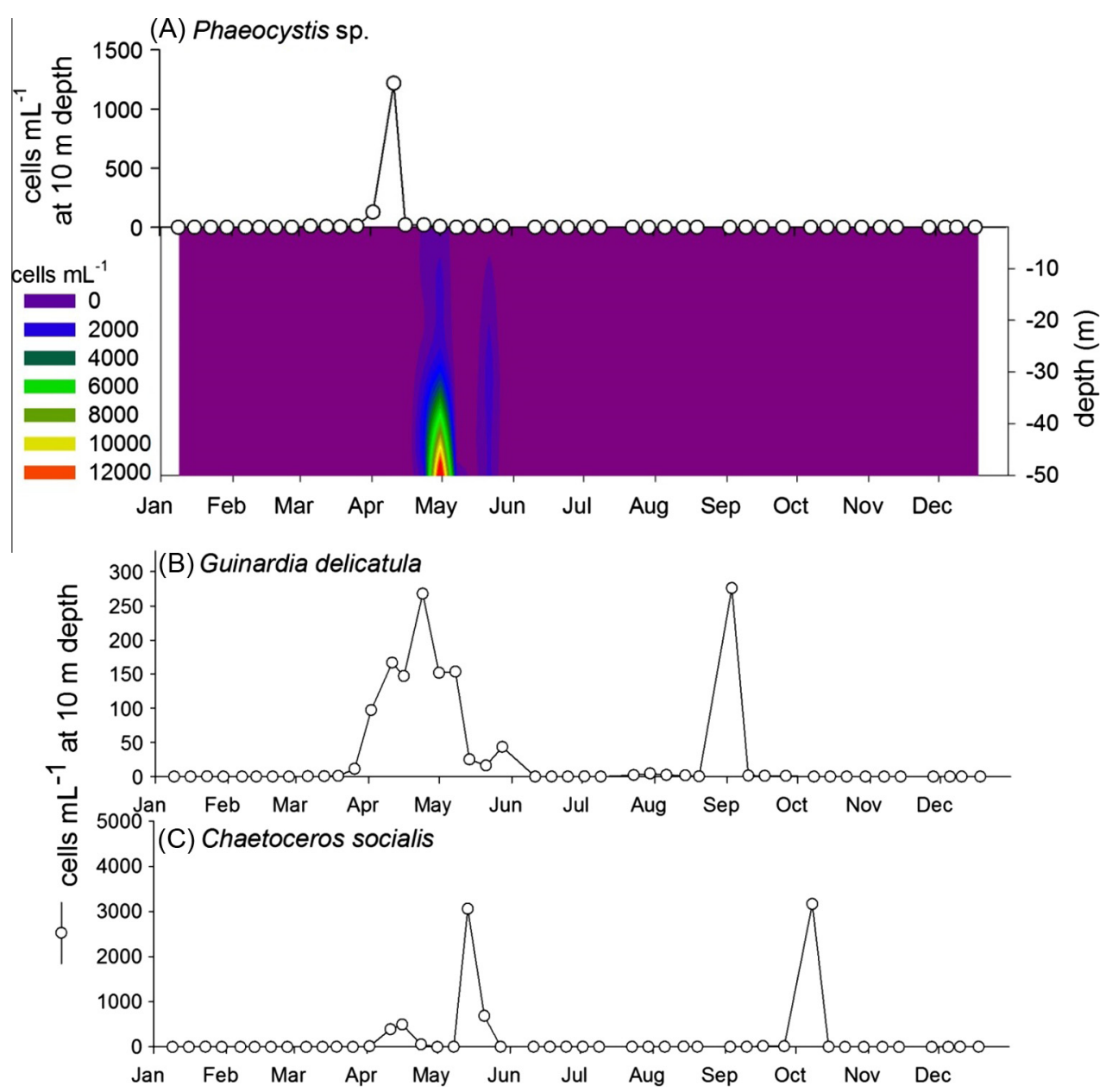

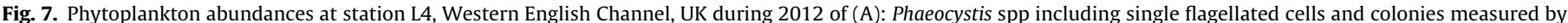

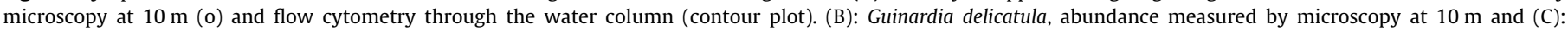
Chaetoceros socialis measured at $10 \mathrm{~m}$ by microscopy.

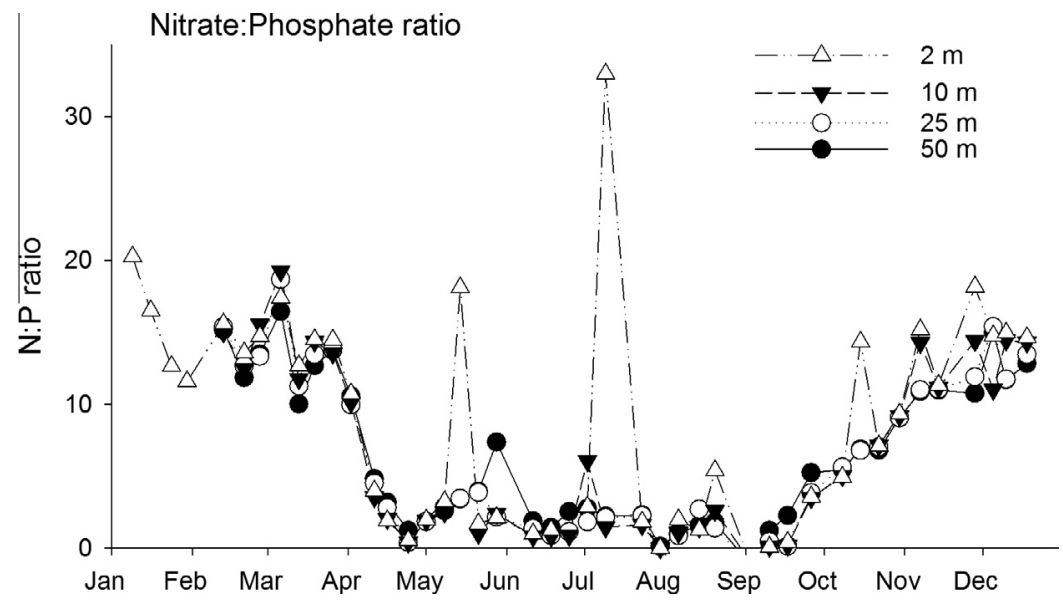

Fig. 8. Ratio of nitrate to phosphate at station L4, Western English Channel, UK during 2012.

during adaptation to low nutrient conditions (Franklin et al., 2012; Bale et al., 2013). However, when infected with viruses, hydroxychlorophyll $a$ increased from $\sim 0.1 \mathrm{fg} \mathrm{cell}^{-1}$ to $\sim 0.33 \mathrm{fg} \mathrm{cell}^{-1}$ (Bale et al., 2013). The ratio of HO-chl- $a$ to chl- $a$ can be calculated to increase from $\sim 0.006$ to $\sim 0.035$ during decline due to viral infection in culture. Thus the increase in HO-chl- $a$, relative to chl- $a$ may prove to be a useful indicator of viral infection, but this must be assessed further in a wider range of phytoplankton taxa.
On the 30th July the HO-chl- $a$ to chl- $a$ ratio reached 0.058 at $25 \mathrm{~m}$ (Fig. 6B), which was coincident with the maximum abundance of the dinoflagellate Karenia mikimotoi at $10 \mathrm{~m}$ depth (evident as the initial peak in total dinoflagellate abundance, Fig. 9B). At this time the water column had a MLD of $20 \mathrm{~m}$. A deep water peak in the HO-chl- $a$ to chl- $a$ ratio of 0.052 occurred at $50 \mathrm{~m}$ on the 17th September (Fig. 6B), when the water column was thermally stratified with a MLD of $25 \mathrm{~m}$. This increase in 


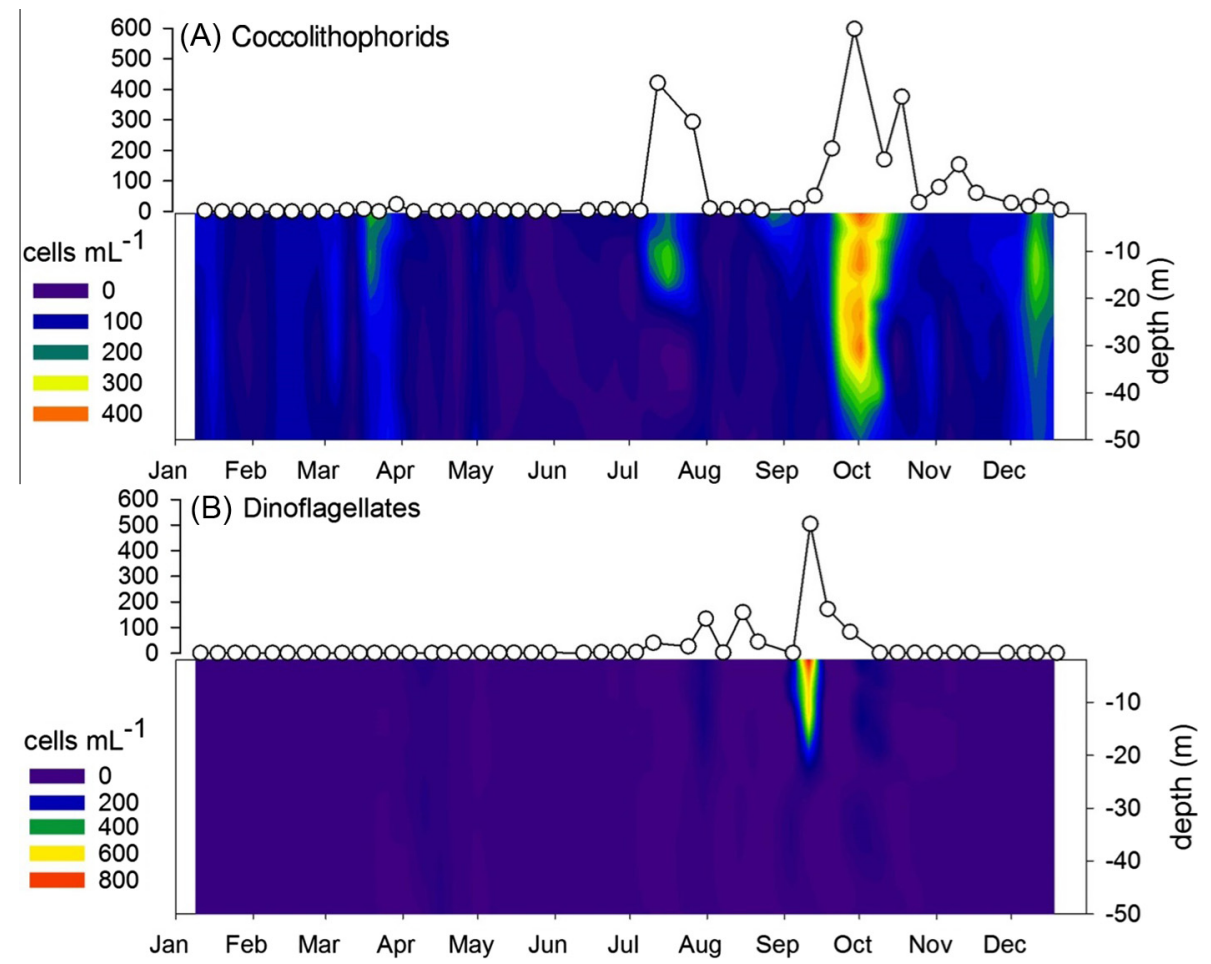

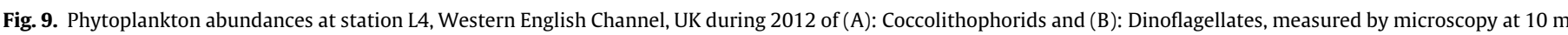
(o) and flow cytometry through the depth profile (contour plot).

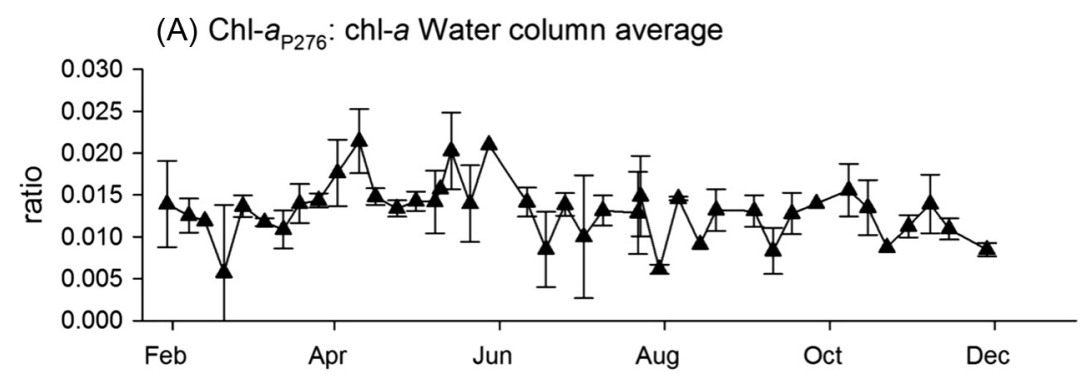

(B) Chl-a $a_{\text {P276 }}:$ chl-a Depth profile

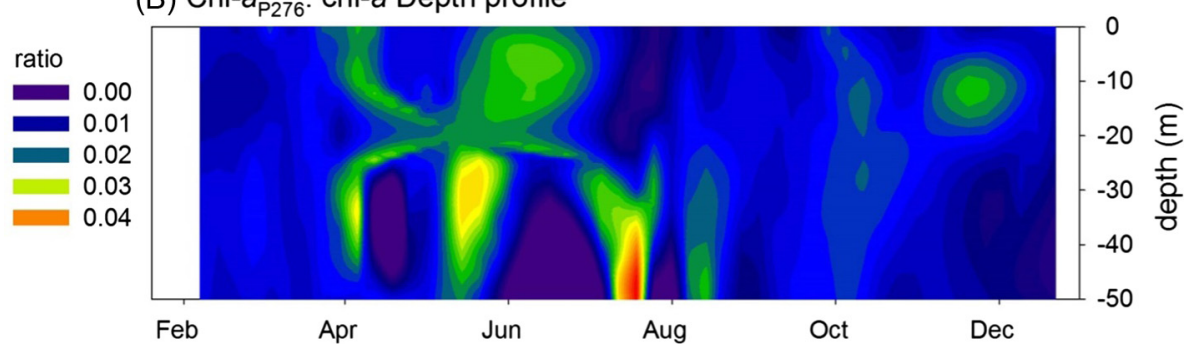

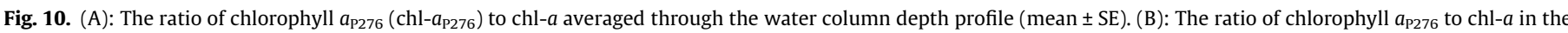
depth profile (contour plot) from station L4, Western English Channel, UK during 2012.

hydroxychlorophyll $a$ followed the maximum dinoflagellate abundance measured by flow cytometry on the 10th of September (Fig. 9B), suggesting a potential contribution to hydroxychlorophyll $a$ from dinoflagellate cells.

\subsubsection{Precursor chlorophyll $a_{P 276}$}

Chlorophyll $a_{\mathrm{P} 276}$ occurred, relative to chl- $a$, with a ratio between 0.003 and 0.027 (Fig. 10). The ratio of chl- $a_{\mathrm{P} 276}$ to chl- $a$ increased between April and July with higher ratios measured at
25 and $50 \mathrm{~m}$ depth compared to surface waters. This period of increased chl- $a_{\mathrm{P} 276}$ (relative to chl- $a$ ) coincides with the period of high phytoplankton abundance (Fig. $4 \mathrm{~A}$ and B), i.e. the spring bloom period. The chl- $a_{\mathrm{P} 276}$ to chl- $a$ ratio maxima occurred before the chlorophyll $a$ maxima (Figs. 5A and 10A). The ratio of chl- $a_{\mathrm{P} 276}$ to chl- $a$ correlates with chl- $a$ concentration $(P<0.001$, rank correlation coefficient $=0.446$ ). This is expected and adds support for the assignment of chl- $a_{\mathrm{P} 276}$ as a precursor during chl- $a$ biosynthesis (Rüdiger, 2006; Franklin et al., 2012). Chlorophyll $a_{\mathrm{P} 276}$ has been 
detected previously in Pavlova gyrans cultures at a ratio of $\sim 0.003$ with chl- $a$ (Bale et al., 2010) which is consistent with the ratios found in this study. Chl- $a_{\mathrm{P} 276}$ has also been detected in cultures of E. huxleyi and Thalasiosira pseudonana (Franklin et al., 2012).

\section{Conclusions}

Chlorophyll $a_{\mathrm{P} 276}$ correlates with chl- $a$ concentration, thus supporting its assignment as a chl- $a$ precursor. The annual trend in the hydroxychlorophyll $a$ to chl- $a$ ratio shown in the present study indicates that formation of HO-chl- $a$ is a variable process in the water column, in this case associated with Phaeocystis spp., G. delicatula, C. socialis and E. huxleyi population dynamics and, reported for the first time, during dinoflagellate blooms. However, the inconsistency of the species' associations with hydroxychlorophyll a suggests a dependency on the mode of phytoplankton mortality or population decline, as has been observed in E. huxleyi cultures (Bale et al., 2013).

A link between hydroxychlorophyll $a$ and phytoplankton mortality was previously postulated by Walker and Keely (2004), where HO-chl- $a$ maxima were observed slightly below the chl- $a$ maxima in the water column, which provided evidence that HO-chl- $a$ was formed after chlorophyll was released from unidentified phytoplankton during senescence or herbivory. In comparison, HO-chl- $a$ to chl- $a$ has been found to be consistent in the water column during a diatom bloom and not linked to any particular ecological processes (Bale et al., 2015). Due to the weekly sampling resolution of this study, it remains challenging to relate hydroxychlorophyll $a$ production more precisely to the population dynamics of this phytoplankton assemblage. To determine which taxa are responsible for allomer production in natural systems, further assessment in laboratory studies is necessary. Analysis across a diverse array of phytoplankton taxa subjected to viral lysis, environmental limitation and grazing will clarify their occurrence in natural systems.

During periods of thermal stratification the HO-chl- $a$ to chl- $a$ ratio was higher below the thermocline. Further, the HO-chl- $a$ to chl- $a$ ratio measured in the sediment was 10 times that detected in the water column, indicating that the process of sedimentation or the processing of phytoplankton cells by other organisms within the water column or at the sediment surface, is a larger contributor to hydroxychlorophyll $a$ than production in phytoplankton cells suspended in the water column.

\section{Contributors}

Deborah J. Steele - Processing raw HPLC data files, data interpretation, article author.

Glen A. Tarran - L4 flow cytometry analysis and processing major article suggestions and text edits.

Claire E. Widdicombe - L4 phyto- and microzooplankton time-series analysis and processing, text suggestions and edits.

E. Malcolm S. Woodward - L4 nutrient time-series analysis and processing, text suggestions and edits.

Susan A. Kimmance - Discussion of data interpretation, major text suggestions and edits.

Daniel J. Franklin - Discussion of data interpretation, text suggestions and edits.

Ruth L. Airs - Original research idea, overseeing HPLC sample collection and HPLC analysis, discussion of data interpretation, manuscript structuring and major text edits.

\section{Role of the funding source}

NERC - no involvement.

\section{Acknowledgements}

We would like to thank all who contributed to the Western Channel Observatory, in particular Dr. James Fishwick, Denise Cummings, Carolyn Harris, Gunjan Motwani and the crew of the Plymouth Marine Laboratory RV Plymouth Quest. The Western Channel Observatory is funded by the UK Natural Environmental Research Council under National Capability. D.J. Steele acknowledges support from a doctoral studentship from the U.K. Natural Environment Research Council; ref NE/I528034/1.

\section{References}

Admiraal, W., Venekamp, L.A.H., 1986. Significance of tintinnid grazing during blooms of Phaeocystis pouchetii (Haptophyceae) in Dutch coastal waters. Netherlands Journal of Sea Research 20, 61-66.

Airs, R.L., Atkinson, J.E., Keely, B.J., 2001. Development and application of a high resolution liquid chromatographic method for the analysis of complex pigment distributions. Journal of Chromatography 917, 167-177.

Airs, R.L., Keely, B.J., 2000. A novel approach for sensitivity enhancement in atmospheric pressure chemical ionisation liquid chromatography/mass spectrometry of chlorophylls. Rapid Communications in Mass Spectrometry 14, 125-128.

Alonso-Laita, P., Agustí, S., 2006. Contrasting patterns of phytoplankton viability in the subtropical NE Atlantic Ocean. Aquatic Microbial Ecology 43, 67-78.

Arrigo, K.R., Perovich, D.K., Pickart, R.S., Brown, Z.W., van Dijken, G.L., Lowry, K.E., Mills, M.M., Palmer, M.A., Balch, W.M., Bates, N.R., 2014. Phytoplankton blooms beneath the sea ice in the Chukchi Sea. Deep Sea Research Part II: Topical Studies in Oceanography.

Baker, E.W., Louda, J.W., 1986. Porphyrins in the geological record. In: Johns, R.B. (Ed.), Methods in Geochemistry and Geophysics. Elsevier, Amsterdam.

Bale, N., 2010. Type I and Type II chlorophyll a transformation products associated with phytoplankton fate processes. PhD, University of Bristol., Unpublished.

Bale, N.J., Airs, R.L., Martin, P., Lampitt, R.S., Llewellyn, C.A., 2015. Chlorophyll-a transformations associated with sinking diatoms during termination of a North Atlantic spring bloom. Marine Chemistry 172, 23-33.

Bale, N.J., Airs, R.L., Kimmance, S., Llewellyn, C.A., 2013. Transformation of chlorophyll a during viral infection of Emiliania huxleyi. Aquatic Microbial Ecology 69, 205-210.

Bale, N.J., Airs, R.L., Llewellyn, C.A., 2011. Type I and Type II chlorophyll a transformation products associated with algal senescence. Organic Geochemistry 42, 451-464.

Bale, N.J., Llewellyn, C.A., Airs, R.L., 2010. Atmospheric pressure chemical ionisation liquid chromatography/mass spectrometry of type II chlorophyll a transformation products: diagnostic fragmentation patterns. Organic Geochemistry 41, 473-481.

Baudoux, A.C. Veldhuis, M.J.W., Noordeloos, A.A.M., van Noort, G., Brussaard, C.P.D. 2008. Estimates of virus vs. grazing induced mortality of picophytoplankton in the North Sea during summer. Aquatic Microbial Ecology 52, 69-82.

Berges, J.A., Falkowski, P.G., 1998. Physiological stress and cell death in marine phytoplankton: induction of proteases in response to nitrogen or light limitation. Limnology and Oceanography 43, 129-135.

Berman-Frank, I., Bidle, K.D., Haramaty, L., Falkowski, P.G., 2004. The demise of the marine cyanobacterium, Trichodesmium spp., via an autocatalyzed cell death pathway. Limnology and Oceanography 49, 997-1005.

Brewer, P.G., Riley, J.P., 1965. The automatic determination of nitrate in sea water. Pages 765-772 in Deep Sea Research and Oceanographic Abstracts. Elsevier.

Brussaard, C.P.D., 2004. Viral control of phytoplankton populations - a review. Journal of Eukaryotic Microbiology 51, 125-138.

Brussaard, C.P.D., Riegman, R., Noordeloos, A.A.M., Cadeé, G.C., Witte, H., Kop, A.J., Nieuwland, G., Van Duyl, F.C., Bak, R.P.M., 1995. Effects of grazing, sedimentation and phytoplankton cell lysis on the structure of a coastal pelagic food web. Marine Ecology Progress Series 123, 259-271.

Cariou-Le Gall, V., Rosell-Mele, A., Maxwell, J., 1998. Data report: Characterization of distributions of photosynthetic pigments in sapropels from holes 966D and 969C1. Pages 297-302 in Proceedings of the Ocean Drilling Program, Scientific Results.

Chen, N., Bianchi, T.S., Bland, J.M., 2003. Implications for the role of pre- versus postdepositional transformation of chlorophyll $a$ in the Lower Mississippi River and Louisiana shelf. Marine Chemistry 81, 37-55.

Currie, R.I., 1962. Pigments in zooplankton Faeces. Nature 193, 956-957.

Elser, J.J., Bracken, M.E., Cleland, E.E., Gruner, D.S., Harpole, W.S., Hillebrand, H., Ngai, J.T., Seabloom, E.W., Shurin, J.B., Smith, J.E., 2007. Global analysis of nitrogen and phosphorus limitation of primary producers in freshwater, marine and terrestrial ecosystems. Ecology Letters 10, 1135-1142.

Fileman, E., Petropavlovsky, A., Harris, R., 2010. Grazing by the copepods Calanus helgolandicus and Acartia clausi on the protozooplankton community at station L4 in the Western English Channel. Journal of Plankton Research, fbp142.

Franklin, D.J., Airs, R.L., Fernandes, M., Bell, T., Bongaerts, R.J., Berges, J.A., Malin, G., 2012. Identification of senescence and death in Emiliania huxleyi and Thalassiosira pseudonana: cell staining, chlorophyll alterations and 
dimethylsulfoniopropionate (DMSP) metabolism. Limnology and Oceanography 57, 305-317.

Grasshoff, K., 1976. Methods of Seawater Analysis. Verlag Chemie, Weinheim.

Head, E.J.H., Hargrave, B.T., Rao, D.V.S., 1994. Accumulation of a pheophorbide- $a$ like pigment in sediment traps during late stages of a spring bloom: a product of dying algae? Limnology and Oceanography 39, 176-181.

Head, E.J.H., Horne, E.P.W., 1993. Pigment transformation and vertical flux in an area of convergence in the North Atlantic. Deep Sea Research Part II: Topical Studies in Oceanography 40, 329-346.

Hodgson, D.A., McMinn, A., Kirkup, H., Cremer, H., Gore, D., Melles, M., Roberts, D., Montiel, P., 2003. Colonization, succession, and extinction of marine floras during a glacial cycle: a case study from the Windmill Islands (east Antarctica) using biomarkers. Paleoceanography 18.

Hodgson, D.A., Roberts, D., McMinn, A., Verleyen, E., Terry, B., Corbett, C., Vyverman, W., 2006. Recent rapid salinity rise in three East Antarctic lakes. Journal of Paleolimnology 36, 385-406.

Holligan, P.M., Harbour, D.S., 1977. The vertical distribution and succession of phytoplankton in the western English Channel in 1975 and 1976. Journal of the Marine Biological Association of the United Kingdom 57, 1075-1093.

Hooker, S.B., Van Heukelem, L., Thomas, C.S., Claustre, H., Ras, J., Schlüter, L., Perl, J., Trees, C., Stuart, V., Head, E., Barlow, R., Sessions, H., Clementson, L., Fishwick, J., Llewellyn, C., Aiken, J., 2005. The Second SeaWiFS HPLC Analysis Round-Robin Experiment (SeaHARRE-2). NASA Tech. Memo. 2005-212785, NASA Goddard Space Flight Center, Greenbelt, Maryland, 112 pp.

Jacobsen, A., Bratbak, G., Heldal, M., 1996. Isolation and characterization of a virus infecting Phaeocystis pouchetii (Prymnesiophyceae). Journal of Phycology 32 (6), 923-927.

Jeffrey, S.W., Hallegraeff, G.M., 1987. Chlorophyllase distribution in ten classes of phytoplankton: a problem for chlorophyll analysis. Marine Ecology Progress Series 35, 293-304.

Keely, B.J., 2006. Geochemistry of chlorophylls. In Advances in Photosynthesis and Respiration. In: Grimm, B., Porra, R.J., Rüdiger, W., Scheer, H. (Eds.). Springer, Dordrecht, The Netherlands.

Kirkwood, D.S., 1989. Simultaneous determination of selected nutrients in sea water. International Council for the Exploration of the Sea (ICES) CM, 100, 29.

Kovala, P.E., Larrance, J.D., 1966. Computation of phytoplankton cell numbers, cell volume, cell surface and plasma volume per liter, from microscopical counts. DTIC Document

Lancelot, C., 1983. Factors affecting phytoplankton extracellular release in the Southern Bight of the North Sea. Marine Ecology Progress Series 12, $115-121$.

Louda, J.W., Li, J., Liu, L., Winfree, M.N., Baker, E.W., 1998. Chlorophyll a degradation during cellular senescence and death. Organic Geochemistry 29, 1233-1251.

Louda, J.W., Mongkhonsri, P., Baker, E.W., 2011. Chlorophyll degradation during senescence and death-III: 3-10yr experiments, implications for ETIO series generation. Organic Geochemistry 42, 688-699.

Louda, W.J., Liu, L., Baker, E.W., 2002. Senescence and death related alteration of chlorophylls and carotenoids in marine phytoplankton. Organic Geochemistry 33, 1635-1653.

Marañón, E., Cermeño, P., Huete-Ortega, M., López-Sandoval, D.C., MouriñoCarballido, B., Rodríguez-Ramos, T., 2014. Resource supply overrides temperature as a controlling factor of marine phytoplankton growth. PLoS ONE 9, e99312.

Menden-Deuer, S., Lessard, E.J., 2000. Carbon to volume relationships for dinoflagellates, diatoms, and other protist plankton. Limnology and Oceanography 45, 569-579.

Rees, A.P., Hope, S.B., Widdicombe, C.E., Dixon, J.L., Woodward, E.M.S., Fitzsimons, M.F., 2009. Alkaline phosphatase activity in the western English Channel: elevations induced by high summertime rainfall. Estuarine, Coastal and Shelf Science $81,569-574$.

Regaudie-de-Gioux, A., Duarte, C.M., 2012. Temperature dependence of planktonic metabolism in the ocean. Global Biogeochemical Cycles 26.

Rousseau, V., Chrétiennot-Dinet, M.-J., Jacobsen, A., Verity, P., Whipple, S., 2007. The life cycle of Phaeocystis: state of knowledge and presumptive role in ecology. Biogeochemistry 83, 29-47.

Rüdiger, W., 2006. Biosynthesis of chlorophylls a and b: the last steps. In: Grimm, B., Porra, R.J., Rudiger, W., Scheer, H. (Eds.). Chlorophylls and Bacteriochlorophyll. Springer.

Smyth, T.J., Fishwick, J.R., Lisa, A.-M., Cummings, D.G., Harris, C., Kitidis, V., Rees, A., Martinez-Vicente, V., Woodward, E.M., 2010. A broad spatio-temporal view of the Western English Channel observatory. Journal of Plankton Research 32 585-601.

Smyth, T.J., Allen, I., Atkinson, A., Bruun, J.T., Harmer, R.A., Pingree, R.D. Widdicombe, C.E., Somerfield, P.J., 2014. Ocean net heat flux influences seasonal to interannual patterns of plankton abundance. PLoS ONE 9 (6), e98709. http://dx.doi.org/10.1371/journal.pone.0098709.

Southward, A.J., Langmead, O., Hardman-Mountford, N.J., Aiken, J., Boalch, G.T. Dando, P.R., Genner, M.J., Joint, I., Kendall, M.A., Halliday, N.C., 2004. Long-term oceanographic and ecological research in the western English Channel Advances in Marine Biology 47, 1-105.

Squier, A.H., Hodgson, D.A., Keely, B.J., 2004. Structures and profiles of novel sulfurlinked chlorophyll derivatives in an Antarctic lake sediment. Organic Geochemistry 35, 1309-1318.

Strzepek, R.F., Hunter, K.A., Frew, R.D., Harrison, P.J., Boyd, P.W., 2012. Iron-light interactions differ in Southern Ocean phytoplankton. Limnology and Oceanography 57, 1182.

Suttle, C.A., Chan, A.M., Cottrell, M.T., 1990. Infection of phytoplankton by viruses and reduction of primary productivity. Nature 347, 467-469.

Szymczak-Żyła, M., Kowalewska, G., 2007. Chloropigments $a$ in the Gulf of Gdańsk (Baltic Sea) as markers of the state of this environment. Marine Pollution Bulletin 55, 512-528.

Tait, K., Airs, R.L., Widdicombe, C.E., Tarran, G.A., Jones, M.R., Widdicombe, S. 2015. Dynamic responses of the benthic bacterial community at the Western English Channel observatory site L4 are driven by deposition of fresh phytodetritus. Progress in Oceanography. http://dx.doi.org/10.1016/j.pocean. 2015.04.020 (this issue).

Tarran, G.A., Bruun, J.T., 2015. Nanoplankton and picoplankton in the Western English Channel: Seasonality and variability from 2007-2013. Progress in Oceanography (this issue).

Treibs, A., 1936. Chlorophyll and hemin derivatives in organic material Angewandte Chemie 49, 682-686 (International Edition).

Utermöhl, H., 1958. Zur vervollkommnung der quantitativen phytoplankton methodik. Mitteilungen Internationale Vereinigung für Theoretische und Angewandte Limnologie 9, 1-38.

Van Heukelem, L., Hooker, S.B., 2011. The importance of a quality assurance plan for method validation and minimizing unceryainties in the HPLC analysis of phytoplankton pigments. In: Roy, S., Llewellyn, C.A., Egeland, E.S., Johnsen, G. (Eds.). Phytoplankton Pigments, Characterization, Chemotaxonomy and Application sin Oceanography. Cambridge University Press. ISBN: 9781107000667.

Veldhuis, M., Colijn, F., Venekamp, L., 1986. The spring bloom of Phaeocystis pouchetii (Haptophyceae) in Dutch coastal waters. Netherlands Journal of Sea Research 20, 37-48.

Walker, S.J., Keely, B.J., 2004. Distribution and significance of chlorophyll derivatives and oxidation products during the spring phytoplankton bloom in the Celtic Sea April 2002. Organic Geochemistry 35, 1289-1298.

Walker, S.J., Squier, A.H., Hodgson, D.A., Keely, B.J., 2002. Origin and significance of $13^{2}$-hydroxychlorophyll derivatives in sediments. Organic Geochemistry 33, 1667-1674.

Walsh, J., 1983. Death in the sea: enigmatic phytoplankton losses. Progress in Oceanography 12, 1-86.

Wang, S., Bailey, D., Lindsay, K., Moore, K., Holland, M., 2014. Impacts of sea ice on the marine iron cycle and phytoplankton productivity. Biogeosciences Discussions 11, 2383-2418.

Welschmeyer, N.A., 1994. Fluorometric analysis of chlorophyll $a$ in the presence of chlorophyll $b$ and pheopigments. Limnology and Oceanography 39, 1985-1992.

Widdicombe, C.E., Eloire, D., Harbour, D., Harris, R.P., Somerfield, P.J., 2010. Longterm phytoplankton community dynamics in the Western English Channel. Journal of Plankton Research 32, 643-655.

Woodward, E.M.S., Rees, A.P., 2001. Nutrient distributions in an anticyclonic eddy in the northeast Atlantic Ocean, with reference to nanomolar ammonium concentrations. Deep Sea Research Part II: Topical Studies in Oceanography $48,775-793$.

Zapata, M., Rodríguez, F., Garrido, J.L., 2000. Separation of chlorophylls and carotenoids from marine phytoplankton: a new HPLC method using a reversed phase C8 column and pyridine-containing mobile phases. Marine Ecology Progress Series 195, 29-45.

Zhang, J.-Z., Chi, J., 2002. Automated analysis of nanomolar concentrations of phosphate in natural waters with liquid waveguide. Environmental Science and Technology 36, 1048-1053. 